\title{
A Multivariate Statistical Research on Engagement of University Students: A Case Study in Greece
}

\author{
Ioannis S. Triantafyllou \\ Department of Computer Science and Biomedical Informatics, University of Thessaly, Lamia, Greece
}

Email address:

itriantafyllou@uth.gr

\section{To cite this article:}

Ioannis S. Triantafyllou. A Multivariate Statistical Research on Engagement of University Students: A Case Study in Greece. American Journal of Theoretical and Applied Statistics. Vol. 5, No. 3, 2016, pp. 94-100. doi: 10.11648/j.ajtas.20160503.13

Received: April 7, 2016; Accepted: April 18, 2016; Published: April 28, 2016

\begin{abstract}
In the present article we study the engagement of University students. Data drawn from the Faculty of Health and Caring Professions of a Greek University, are properly analyzed via inferential statistics in order to detect characteristics that affect significantly the engagement of students. Factor analysis has been also applied and revealed the expected structure of the measurement scale that has been used. Moreover, cluster analysis based on total score contributed to the identification of the crucial role of several demographics.
\end{abstract}

Keywords: Utrecht Work Engagement Scale, University Students, Factor Analysis, $k$-means Cluster Analysis

\section{Introduction}

During the last decades, work engagement has attracted a lot of research attention. Since Kahn [8] introduced the notion of engagement, determining that engaged employees put a great deal of effort into their work because they identify with it, two main tendencies appeared in the literature considering work engagement as a positive, work-related state of well-being or fulfillment. More specifically, Maslach $\&$ Leiter [10] claimed that engagement is characterized by energy, involvement and efficacy, allocating it as the opposite of burnout, which is defined in terms of exhaustion, cynicism and ineffectiveness. According to their approach, engagement and burnout constitute the opposite poles of a continuum of work related well-being, with burnout representing the negative and engagement the positive one.

However, assessing both burnout and engagement by the same questionnaire, leads to difficulties and possible false conclusions when interpreting the research's outcomes (see, e.g. [15]). The alternative view considers work engagement to be an independent, distinct concept that is negatively related to burnout (see, e.g. [16]). Consequently, work engagement is defined as a positive, fulfilling, work-related state of mind that is characterized by vigor, dedication and absorption (see, e.g. [12]). In words, vigor is characterized by the willingness to invest effort in one's work and persistence even in the face of difficulties. Dedication refers to being strongly involved in one's work and experiencing a sense of enthusiasm and challenge, while absorption is related to being fully concentrated and happily engrossed in one's work, whereby time passes quickly. For more details about the characterization of work engagement and related concepts, the interested reader is referred to the excellent studies [1], [2], [6] or [14].

Within the framework of the latter approach, a self-report questionnaire, called the Utrecht Work Engagement Scale (UWES hereafter), has been developed including the aforementioned constituting aspects of work engagement (see, e.g. [15]). More precisely, vigor is assessed by items $V I$ 1-6, which refer to high levels of energy and resilience while working. According to vigor's subscale, high score is interpreted as having much energy, zest and stamina when working, whereas low score as the opposite situation. Moreover, dedication is assessed by items $D E 1-5$, which refer to deriving a sense of significance from one's work. According to dedication's subscale, those who score high on dedication identify strongly with their work. Finally, absorption is measured by items $A B$ 1-6, where high score coincides with being totally and happily immersed in one's work. For a detailed presentation of several versions of UWES, one may refer to [15].

Generally speaking, work engagement has attracted a lot of research attention in the recent literature. Bakker et al. 
[13] examined how work engagement and workaholism are related to family satisfaction as reported by Japanese employees and their intimate partner. In addition, Breevaart et al. [4] investigated the contribution of transformational leadership behaviors as well as employee self-leadership strategies to employee work engagement and performance. On the other hand, Breevaart et al. [5] studied the relationship between leader-member exchange and employee job performance and how this connection can be mediated by job resources and employee work engagement. Besides, Feldt et al. [7] aimed at identifying long-term patterns of effortreward imbalance and over-commitment and examining how occupational well-being and recovery experiences differ in these patterns. For a detailed and up-to-date presentation of findings on the long-term development of employee wellbeing, the interested reader is referred to the excellent review paper [9].

It is worth mentioning that the original version of UWES included 24 items. However, after psychometric evaluation in various samples of employees and students, 7 items appeared to be unsound and were therefore eliminated ([11]). The resulting 17-items version of the UWES, which is applied in the present research, has been also used in many studies. For example, Schaufeli, Taris and Van Rhenen [13] confirmed that the hypothesized three-factor structure of UWES is superior to the one-factor model, Schaufeli et al. [12] investigated burnout and engagement in university students, while Sonnentag [17] showed that the level of experienced work engagement is positively associated with the extent to which employees recovered from their previous working day.

In the present article, the 17-items UWES has been employed in a sample of students from the Faculty of Health and Caring Professions of a Greek University. The outcome of the research confirmed the expected three-factor structure of UWES, while several conclusions concerning the connection between quantitative or qualitative characteristics and engagement of students, have been reached. Section 2 describes briefly the appropriate statistical methodologies that have been applied, while Section 3 presents in detail the results established. Finally, Section 4 offers a collective summary of deductions and some thoughts for further research.

\section{Methods}

A total of 341 students of Technological Educational Institute of Athens took part in the study. All participants were students of Faculty of Health and Caring Professions of the aforementioned University. The 17-items UWES questionnaires were distributed to all students present at the end of randomly chosen lectures. Those who did not want to participate were asked to simply return a blank form. Note that the response rate was approximately equal to $85 \%$. In addition, all respondents were also asked some general questions referring to demographics or other characteristics (see Questions GQ 1-7 in Appendix I).

UWES contains 17 statements about work engagement (see, [15] and the Appendix therein), to which participants are asked to rate their degree of agreement. The aforementioned instrument uses a 7-level Likert-type scale with responses ranging from Never, Almost Never, Rarely, Sometimes, Often, Very Often and Always. High scores suggest that students feel engaged to their duty, whereas low scores reflect the opposite situation.

Among 341 students approached, $21.4 \%$ of them were males, while the rest $78.6 \%$ were females. In addition, $24.9 \%$ of participants were students of Department of Medical Radiologic Technology, 23.5\% of them were students of Department of Dental Technology, 28.4\% of respondents belonged to Department of Midwifery, while the rest 23.3\% were students of Department of Occupational Therapy. Moreover, approximately $40 \%$ of total sample represented $1^{\text {st }}$ grade (year) students, while the remaining $60 \%$ were students of $2^{\text {nd }}, 3^{\text {rd }}$ or $4^{\text {th }}$ grade (year).

Differences in UWES scorings between various subgroups were explored applying appropriate inferential statistics ( $T$-test or $F$-test). By using Bonferonni post-hoc tests, multiple comparisons were constructed.. In order to investigate whether several quantitative or qualitative characteristics of students contributed significantly to UWES score, Pearson correlations and Chi-square tests were established. In addition, Factor analysis has been employed in order to determine the multi-component structure of the questionnaire. The solution has been rotated applying the Varimax method with Kaiser normalization. Adequacy and reliability measures of the study have been also calculated. Finally, $k$-means clustering methodology led to some interesting remarks referring to the connection between UWES scoring and demographics. Please note that the statistical analysis was carried out by using IBM SPSS Statistics 23.0.

\section{Main Results}

Table 1. Utrecht Work Engagement Scale (UWES) mean scores in different sub-samples.

\begin{tabular}{llll}
\hline Study Sample & N & $\begin{array}{l}\text { Mean UWES } \\
\text { score (SD) }\end{array}$ & $\begin{array}{l}\text { Test statistic (p- } \\
\text { value) }\end{array}$ \\
\hline Total & 341 & $3.79(0.98)$ & \\
Males & 73 & $3.65(0.97)$ & \\
Females & 268 & $3.83(0.98)$ & $-1.46(0.145)^{1}$ \\
Medical Radiologic Technology & 85 & $3.83(0.99)$ & \\
Dental Technology & 80 & $3.68(0.97)$ & \\
Occupational Therapy & 79 & $3.78(0.94)$ & \\
Midwifery & 97 & $3.88(1.00)$ & $0.65(0.583)^{2}$ \\
High School Graduation's & 58 & $3.54(1.10)$ & \\
$\begin{array}{l}\text { Degree: Low/Moderate } \\
\text { High School Graduation's }\end{array}$ & 283 & $3.85(0.94)$ & $-2.17(0.031)^{1}$ \\
Degree: Good/Very Good & 136 & $3.94(0.91)$ & \\
$1^{\text {st }}$ Year & 205 & $3.70(1.01)$ & $2.262(0.024)^{1}$ \\
$2^{\text {nd }} 3^{\text {rd }}$ or $4^{\text {th }}$ Year & & & \\
\hline
\end{tabular}

1. T-test 2. F-test

In this section, we present the main results of the research referring to work engagement of students that took place in Technological Educational Institute of Athens. Table 1 
depicts the UWES mean scores in several sub-samples, while $T$-test and $F$-test highlight statistically significant group differences. As we may easily observe, students, whose High School's Graduation Degree was at least Good, exhibited significantly larger UWES mean scores than those with High School's Graduation Degree at most Moderate. Moreover, $1^{\text {st }}$ year students feel significantly more engaged versus students of higher grade.

Concerning the Vigor sub-scale (sub-score for items VI 16), Table 2 reveals that the only significant difference (superiority) is detected between $1^{\text {st }}$ year students against the others. In words, $1^{\text {st }}$ year students have much more energy, zest and stamina when working, in comparison with rest students.

Table 2. Vigor sub-scale mean scores in different sub-samples.

\begin{tabular}{llll}
\hline Study Sample & N & $\begin{array}{l}\text { Mean Vigor } \\
\text { score (SD) }\end{array}$ & $\begin{array}{l}\text { Test statistic } \\
\text { (p-value) }\end{array}$ \\
\hline Total & 341 & $3.61(1.04)$ & \\
Males & 73 & $3.62(0.99)$ & \\
Females & 268 & $3.61(1.06)$ & $0.067(0.946)^{1}$ \\
Medical Radiologic Technology & 85 & $3.73(1.06)$ & \\
$\begin{array}{l}\text { Dental Technology } \\
\text { Occupational Therapy }\end{array}$ & 80 & $3.53(1.01)$ & \\
Midwifery & 79 & $3.56(0.99)$ & \\
High School Graduation's Degree: & 97 & $3.62(1.09)$ & $0.574(0.633)^{2}$ \\
Low/Moderate & 58 & $3.43(1.21)$ & \\
High School Graduation's Degree: & 283 & $3.65(1.00)$ & $-1.452(0.148)^{1}$ \\
Good/Very Good & 136 & $3.76(1.05)$ & \\
$1^{\text {st }}$ Year & 205 & $3.51(1.03)$ & $2.138(0.033)^{1}$ \\
$2^{\text {nd }} 3^{\text {rd }}$ or $4^{\text {th }}$ Year & & & \\
\hline
\end{tabular}

1. T-test 2. F-test

In addition, Table 3 summarizes the conclusions for Dedication sub-scale (sub-score for items $D E$ 1-5). The results for Dedication sub-scale, coincides to the respective outcome referring to total UWES scores interpreted earlier.

Table 3. Dedication sub-scale mean scores in different sub-samples.

\begin{tabular}{llll}
\hline Study Sample & N & $\begin{array}{l}\text { Mean Dedication } \\
\text { score (SD) }\end{array}$ & $\begin{array}{l}\text { Test statistic } \\
\text { (p-value) }\end{array}$ \\
\hline Total & 341 & $4.29(1.14)$ & \\
$\begin{array}{l}\text { Males } \\
\text { Females }\end{array}$ & 73 & $3.62(0.99)$ & $0.067(0.946)^{1}$ \\
$\begin{array}{l}\text { Medical Radiologic } \\
\text { Technology }\end{array}$ & 268 & $3.61(1.06)$ & \\
$\begin{array}{l}\text { Dental Technology } \\
\text { Occupational Therapy }\end{array}$ & 85 & $4.25(1.16)$ & \\
$\begin{array}{l}\text { Midwifery } \\
\text { High School Graduation's }\end{array}$ & 79 & $4.03(1.20)$ & \\
$\begin{array}{l}\text { Degree: Low/Moderate } \\
\text { High School Graduation's }\end{array}$ & 58 & $3.98(1.20)$ & $2.329(0.074)^{2}$ \\
$\begin{array}{l}\text { Degree: Good/Very Good } \\
1^{\text {st }} \text { Year }\end{array}$ & 283 & $4.35(1.12)$ & $-2.252(0.025)^{1}$ \\
$2^{\text {nd }} 3^{\text {rd }}$ or 4 ${ }^{\text {th }}$ Year & 136 & $4.52(0.98)$ & \\
\hline
\end{tabular}

1. T-test 2. F-test

Moreover, when absorption sub-scale (sub-score for items $A B$ 1-6) is under investigation, the Graduation's Degree seems to be the only qualitative characteristic of students that play an important role in being totally and happily immersed in work. Indeed, Table 4 exposes that students with High School Graduation's Degree at least equal to Good, appear to be more absorbed in their studies than the others.

Table 4. Absorption sub-scale mean scores in different sub-samples.

\begin{tabular}{llll}
\hline Study Sample & N & $\begin{array}{l}\text { Mean Absorption } \\
\text { score (SD) }\end{array}$ & $\begin{array}{l}\text { Test statistic } \\
\text { (p-value) }\end{array}$ \\
\hline Total & 341 & $3.56(1.03)$ & \\
Males & 73 & $3.43(0.96)$ & $-1.243(0.215)^{1}$ \\
Females & 268 & $3.60(1.05)$ & \\
Medical Radiologic & 85 & $3.57(0.99)$ & \\
Technology & 80 & $3.52(0.99)$ & \\
Dental Technology & 79 & $3.50(1.04)$ & \\
Occupational Therapy & 97 & $3.64(1.10)$ & $0.288(0.834)^{2}$ \\
Midwifery & 58 & $3.29(1.13)$ & \\
High School Graduation's & & & \\
$\begin{array}{l}\text { Degree: Low/Moderate } \\
\text { High School Graduation's }\end{array}$ & 283 & $3.62(1.00)$ & $-2.264(0.024)^{1}$ \\
$\begin{array}{l}\text { Degree: Good/Very Good } \\
1^{\text {st }} \text { Year }\end{array}$ & 136 & $3.64(1.02)$ & \\
$2^{\text {nd }} 3^{\text {rd }}$ or 4 ${ }^{\text {th }}$ Year & 205 & $3.51(1.04)$ & $1.097(0.273)^{1}$ \\
\hline
\end{tabular}

1. T-test 2. F-test

It is of some research interest, to investigate whether sample data attest the expected structure of 17-items version of UWES, as it has been suggested in the literature (see, e.g. [15]). Confirmatory Factor analysis was applied and the hypothesized three-factor structure of UWES was affirmed with $61.6 \%$ of total variance explained by them (see also the corresponding Scree plot in Appendix II). Kaiser-MeyerOlkin measure was found to be equal to 0.929 , while Bartlett's test of sphericity for the three-factor structure was significant $(p<0.001)$. As it concerns the internal consistency, Cronbach's alpha was computed not only for the 17-items version of UWES (alpha $=0.928$ ), but also for the 6-items Vigor subscale (alpha $=0.829$ ), the 5-items Dedication subscale (alpha $=0.857$ ) and the 6-items Absorption subscale (alpha $=0.802)$ separately. All alpha values exceed 0.80 as it was expected (see, e.g. [6] or [15]). In addition, loadings for the three-component structure of UWES are displayed in Appendix III. Note that the solution was rotated applying the Varimax method with Kaiser normalization. One may easily obtain that Vigor component relies on items $1,4,8,12,15$ and 17 of the 17 -items version of UWES (or VI 1-6 respectively), Dedication component relies on items 2, 5, 7, 10 and 13 (or $D E 1-5$ respectively) and Absorption component relies on items 3, 6, 9, 11, 14 and 16 (or $A B$ 1-6 respectively). Moreover, as it concerns the external reliability of the instrument, a test-retest procedure has been followed within a sub-sample of 63 students and the results confirmed that non-significant differences were observed between test and retest scores $(r=0.995)$.

It is worth mentioning that sub-scores obtained by students at each sub-scale separately, are strongly related. More specifically, Vigor sub-scale score is strongly and positively correlated to Dedication sub-scale $(r=0.696, p<0.001)$ and Absorption sub-scale $(r=0.839, p<0.001)$, while Dedication and Absorption sub-scale scores seem to be significantly connected too $(r=0.729, p<0.001)$. 
Table 5 displays the UWES mean scores in several subsamples based on questions $G Q 1-7$, while $T$-test and $F$-test detect statistically significant group differences.

Table 5. UWES mean scores in sub-samples based on Questions GQ 1-7.

\begin{tabular}{|c|c|c|c|c|}
\hline Question & $\begin{array}{l}\text { Participant's } \\
\text { Reply }\end{array}$ & $\mathbf{N}$ & $\begin{array}{l}\text { UWES mean } \\
\text { score (SD) }\end{array}$ & $\begin{array}{l}\text { Test statistic } \\
\text { (p-value) }\end{array}$ \\
\hline \multirow[t]{2}{*}{$G Q 1$} & Yes & 85 & $3.89(0.92)$ & \multirow{3}{*}{$1.107(0.269)^{1}$} \\
\hline & No & 251 & $3.76(0.99)$ & \\
\hline \multirow[t]{4}{*}{$G Q 2$} & Rarely & 77 & $3.43(1.06)$ & \\
\hline & Quite often & 64 & $3.72(0.96)$ & \\
\hline & Often & 85 & $3.85(1.02)$ & \multirow{3}{*}{$6.376(<0.001)^{2}$} \\
\hline & Almost always & 115 & $4.03(0.83)$ & \\
\hline \multirow[t]{2}{*}{$G Q 3$} & Yes & 322 & $3.83(0.95)$ & \\
\hline & No & 16 & $3.00(1.15)$ & \multirow[t]{2}{*}{$3.366(0.001)^{1}$} \\
\hline \multirow[t]{2}{*}{$G Q 4$} & Yes & 147 & $3.76(0.90)$ & \\
\hline & No & 193 & $3.82(1.04)$ & $-0.531(0.596)^{1}$ \\
\hline \multirow[t]{2}{*}{$G Q 5$} & Yes & 86 & $3.97(0.97)$ & \multirow[b]{2}{*}{$1.927(0.055)^{1}$} \\
\hline & No & 254 & $3.73(0.98)$ & \\
\hline \multirow[t]{2}{*}{$G Q 6$} & Yes & 252 & $3.91(0.93)$ & \multirow{3}{*}{$4.139(<0.001)^{1}$} \\
\hline & No & 87 & $3.42(1.00)$ & \\
\hline \multirow[t]{2}{*}{$G Q 7$} & Yes & 269 & $3.68(1.05)$ & \\
\hline & No & 70 & $3.09(0.85)$ & $4.951(<0.001)^{1}$ \\
\hline
\end{tabular}

1. T-test 2. F-test

One may readily deduce that replies on questions $G Q 2$, $G Q 3, G Q 6$ and $G Q 7$ are strongly related to students' UWES scores. More precisely, we summarize the following conclusions

- Students that are willing to carry on postgraduate studies feel significantly more engaged to their work (studies) than the others $(G Q 7)$.

- Students who feel satisfied with teaching staff of their Department are significantly more engaged to their work (studies) than the others $(G Q 6)$.

- Students who believe that the subject of their Department is accompanied by strong professional perspective are significantly more engaged to their work (studies) than the others $(G Q 3)$.

- Level of regular attendance of students play an important role for UWES score $(G Q$ 2). In fact, Bonferroni pariwise comparisons reveal that students with rare attendance exhibit significantly lower UWES score than those who attend lectures often $(p=0.031)$ or almost always $(p<0.001)$.

Employing analogous methodology, we examine the mean scores of each sub-scale separately, in several sub-samples based on questions $G Q 1-7$. The results are recapitulated in Appendices IV, V and VI, where tables therein lead to the following remarks

- Students that are willing to continue on postgraduate studies exhibit significantly higher scores for sub-scales Vigor, Dedication and Absorption than the other students ( $p<0.001$ for each sub-scale).

- Students that feel satisfied with teaching staff of their Department exhibit significantly higher scores for subscales Vigor, Dedication and Absorption than the other students $(p<0.001, p<0.001$ and $p=0.001$ respectively).

- Students who feel satisfied with administrative staff of their Department exhibit significantly higher scores for sub-scale Vigor than the others $(p=0.009)$.

- Students who believe that the subject of their Department is accompanied by strong professional perspective exhibit significantly higher scores for subscales Vigor, Dedication and Absorption than the other students $(p=0.007, p<0.001$ and $p=0.019$ respectively).

- Level of regular attendance of students play an important role for scores of sub-scales Vigor, Dedication and Absorption. In fact, Bonferonni pariwise comparisons reveal that students with rare attendance exhibit significantly lower Vigor, Dedication and Absorption sub-score than those who attend lectures almost always $(p<0.001, p<0.001$ and $p=0.013$ respectively). In addition, students with rare attendance exhibit significantly lower Vigor sub-score than those who attend lectures often $(p=0.01)$.

Finally, we employ $k$-means clustering, aiming at identifying those qualitative factors that affect strongly the classification procedure. The size and mean scores of each cluster that has been shaped for several values of the parameter $k$ are displayed in Appendix VII. As it was expected, clusters differ significantly from each other for all values of parameter $k$ that were examined. Based on Table 6 , one may deduce some interesting remarks about the clustering results. More specifically, we observe that

- Gender seems to affect strongly the classification membership for $k=3$ and $k=5(p=0.034$ and $p=$ 0.047 respectively).

- High School Graduation's Degree seems to affect strongly the classification membership for $k=2$ and $k=$ 5 ( $p=0.007$ and $p=0.023$ respectively).

- Year of study seems to affect strongly the classification membership for $k=3$ and $k=4(p=0.011$ and $p=$ 0.023 respectively).

Table 6. Pearson Chi-square cross-tabulation results between Classification Membership and Demographics.

\begin{tabular}{lllll}
\hline $\boldsymbol{k}$-means Clustering & Gender & Department & High School Graduation's Degree & Year \\
\hline Membership $(k=2)$ & $1.35(0.245)$ & $2.45(0.484)$ & $7.23(0.007)^{*}$ & $2.86(0.091)$ \\
Membership $(k=3)$ & $6.75(0.034)^{*}$ & $2.29(0.891)$ & $4.38(0.112)$ & $8.94(0.011)^{*}$ \\
Membership $(k=4)$ & $3.45(0.327)$ & $8.42(0.493)$ & $7.12(0.068)$ & $9.56(0.023)^{*}$ \\
Membership $(k=5)$ & $9.64(0.047)^{*}$ & $7.11(0.85)$ & $11.38(0.023)^{*}$ & $8.79(0.067)$ \\
\hline
\end{tabular}

*significant at level $5 \%$ 
Moreover, Table 7 is summarized as follows

- Question $G Q 2$ is significantly connected to the classification membership for all values of parameter $k$ $=2,3,4$ and $5(p<0.001, p<0.001, p=0.003$ and $p<$ 0.001 respectively).

- Question $G Q 3$ is significantly connected to the classification membership for values of parameter $k=2$, 3 and $4(p=0.029, p=0.021$ and $p=0.009$ respectively).
- Question $G Q 6$ is significantly connected to the classification membership for all values of parameter $k$ $=2,3,4$ and $5(p=0.031, p<0.001, p=0.031$ and $p=$ 0.003 respectively).

- Question $G Q 7$ is significantly connected to the classification membership for all values of parameter $k$ $=2,3,4$ and $5(p<0.001, p<0.001, p<0.001$ and $p=$ 0.001 respectively).

Table 7. Pearson Chi-square cross-tabulation results between Classification Membership and Questions GQ 1-7.

\begin{tabular}{|c|c|c|c|c|c|c|c|}
\hline$k$-means Clustering & $G Q 1$ & $G Q 2$ & $G Q 3$ & $G Q 4$ & GQ 5 & $G Q 6$ & $G Q 7$ \\
\hline Membership & 2.53 & 17.78 & 10.77 & 2.66 & 4.58 & 8.85 & 19.70 \\
\hline$(k=2)$ & $(0.639)$ & $(<0.001)^{*}$ & $(0.029)^{*}$ & $(0.264)$ & $(0.101)$ & $(0.031)^{*}$ & $(<0.001)^{*}$ \\
\hline Membership & 8.78 & 29.01 & 18.04 & 3.95 & 4.93 & 24.51 & 23.92 \\
\hline$(k=3)$ & $(0.361)$ & $(<0.001)^{*}$ & $(0.021)^{*}$ & $(0.412)$ & $(0.295)$ & $(<0.001)^{*}$ & $(<0.001)^{*}$ \\
\hline Membership & 6.03 & 24.68 & 26.51 & 4.78 & 7.01 & 18.38 & 24.08 \\
\hline$(k=4)$ & $(0.914)$ & $(0.003)^{*}$ & $(0.009)^{*}$ & $(0.572)$ & $(0.313)$ & $(0.031)^{*}$ & $(0.001)^{*}$ \\
\hline Membership & 10.08 & 36.71 & 23.03 & 8.39 & 6.85 & 29.60 & 28.70 \\
\hline
\end{tabular}

${ }^{*}$ significant at level $5 \%$

\section{Conclusions}

In the present article, we provide a multivariate statistical study of (work) engagement for students of a Faculty of Health and Caring Professions in Greece. The Utrecht Work Engagement Scale has been used in order to measure the engagement that participants feel towards their duty as students. The results of research confirmed the well-known three-factor structure of the aforementioned instrument, while several qualitative characteristics proved to be significant for UWES score. More specifically, High School Graduation's Degree, year of study, willing to continue on postgraduate studies, level of regular attendance or gender seem to affect work engagement of students. It is of some interest for future research, to apply the UWES to different professional groups in Greece and cross-over the outcomes to the corresponding ones drawn from other studies aiming at same pool of employees.

\section{Appendix I}

Table A1. Questions GQ 1-7.

\begin{tabular}{|c|c|}
\hline Question & Reply \\
\hline $\begin{array}{l}G Q 1 \text {. Does any of your relatives work at the same } \\
\text { subject which you study? }\end{array}$ & Yes / No \\
\hline$G Q 2$. How often do you attend lectures? & $\begin{array}{l}\text { Rarely / Quite often / } \\
\text { Often / Almost always }\end{array}$ \\
\hline $\begin{array}{l}G Q 3 \text {. Do you believe that the subject that you } \\
\text { study is accompanied by strong professional } \\
\text { perspective? }\end{array}$ & Yes / No \\
\hline $\begin{array}{l}G Q 4 \text {. Are you satisfied with facilities of your } \\
\text { Department? }\end{array}$ & Yes / No \\
\hline $\begin{array}{l}G Q 5 \text {. Are you satisfied with the administrative } \\
\text { staff of your Department? }\end{array}$ & Yes / No \\
\hline $\begin{array}{l}G Q 6 \text {. Are you satisfied with the teaching staff of } \\
\text { your Department? }\end{array}$ & Yes / No \\
\hline $\begin{array}{l}G Q 7 . \text { Are you willing to carry on postgraduate } \\
\text { studies? }\end{array}$ & Yes / No \\
\hline
\end{tabular}

\section{Appendix II}

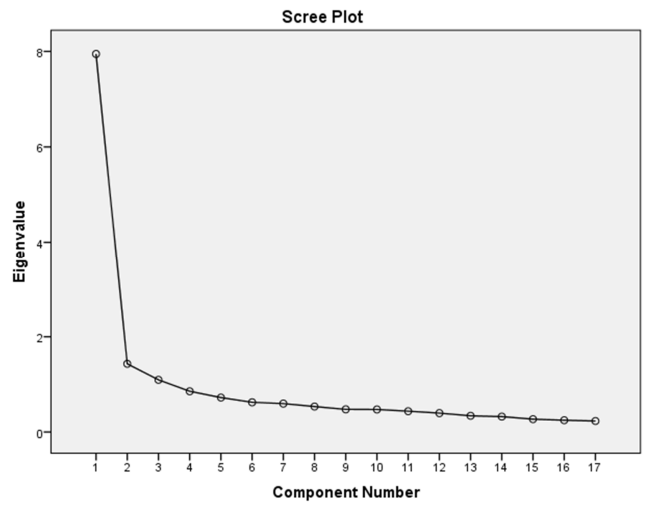

Figure A1. Scree plot reveals the three-factor structure of UWES instrument.

\section{Appendix III}

Table A2. Loadings for three-factor structure of UWES.

\begin{tabular}{|c|c|c|c|}
\hline Item & $\begin{array}{l}\text { Component } 1 \\
\text { Dedication }\end{array}$ & $\begin{array}{l}\text { Component } 2 \\
\text { Vigor }\end{array}$ & $\begin{array}{l}\text { Component } 3 \\
\text { Absorption }\end{array}$ \\
\hline 1 & & 0.126 & \\
\hline 2 & 0.659 & & \\
\hline 3 & & & 0.732 \\
\hline 4 & & 0.249 & \\
\hline 5 & 0.733 & & \\
\hline 6 & & & 0.499 \\
\hline 7 & 0.708 & & \\
\hline 8 & & 0.358 & \\
\hline 9 & & & 0.518 \\
\hline 10 & 0.764 & & \\
\hline 11 & & & 0.331 \\
\hline 12 & & 0.736 & \\
\hline 13 & 0.664 & & \\
\hline 14 & & & 0.278 \\
\hline 15 & & 0.543 & \\
\hline 16 & & & 0.156 \\
\hline 17 & & 0.690 & \\
\hline
\end{tabular}




\section{Appendix IV}

Table A3. Vigor mean scores in sub-samples based on Questions GQ 1-7.

\begin{tabular}{|c|c|c|c|c|}
\hline Question & $\begin{array}{l}\text { Participant's } \\
\text { Reply }\end{array}$ & $\mathbf{N}$ & $\begin{array}{l}\text { Mean Vigor } \\
\text { score (SD) }\end{array}$ & $\begin{array}{l}\text { Test statistic } \\
\text { (p-value) }\end{array}$ \\
\hline \multirow[t]{2}{*}{$G Q 1$} & Yes & 85 & $3.70(1.05)$ & \\
\hline & No & 251 & $3.58(1.03)$ & $0.872(0.384)^{1}$ \\
\hline \multirow[t]{4}{*}{$G Q 2$} & Rarely & 77 & $3.18(1.12)$ & \\
\hline & Quite often & 64 & $3.58(1.02)$ & \\
\hline & Often & 85 & $3.68(1.01)$ & \\
\hline & Almost always & 115 & $3.87(0.93)$ & $7.591(<0.001)^{2}$ \\
\hline \multirow[t]{2}{*}{$G Q 3$} & Yes & 322 & $3.64(1.03)$ & \\
\hline & No & 16 & $2.92(1.07)$ & $2.729(0.007)^{1}$ \\
\hline \multirow[t]{2}{*}{$G Q 4$} & Yes & 147 & $3.64(0.97)$ & \\
\hline & No & 193 & $3.59(1.10)$ & $0.380(0.704)^{1}$ \\
\hline \multirow[t]{2}{*}{$G Q 5$} & Yes & 86 & $3.86(1.00)$ & \\
\hline & No & 254 & $3.53(1.04)$ & $2.618(0.009)^{1}$ \\
\hline \multirow[t]{2}{*}{$G Q 6$} & Yes & 252 & $3.72(0.99)$ & \\
\hline & No & 87 & $3.26(1.09)$ & $3.624(<0.001)^{1}$ \\
\hline \multirow[t]{2}{*}{$G Q 7$} & Yes & 269 & $3.73(1.08)$ & \\
\hline & No & 70 & $3.13(0.93)$ & $4.464(<0.001)^{1}$ \\
\hline
\end{tabular}

1. T-test 2. F-test

\section{Appendix V}

Table A4. Dedication mean scores in sub-samples based on Questions GQ 1-7.

\begin{tabular}{|c|c|c|c|c|}
\hline Question & $\begin{array}{l}\text { Participant's } \\
\text { Reply }\end{array}$ & $\mathbf{N}$ & $\begin{array}{l}\text { Mean Dedication } \\
\text { score (SD) }\end{array}$ & $\begin{array}{l}\text { Test statistic (p- } \\
\text { value) }\end{array}$ \\
\hline \multirow[t]{2}{*}{$G Q 1$} & Yes & 85 & $4.41(1.03)$ & \\
\hline & No & 251 & $4.25(1.19)$ & $1.116(0.265)^{1}$ \\
\hline \multirow[t]{4}{*}{$G Q 2$} & Rarely & 77 & $3.94(1.19)$ & \\
\hline & Quite often & 64 & $4.14(1.17)$ & \\
\hline & Often & 85 & $4.30(1.30)$ & \\
\hline & Almost always & 115 & $4.60(0.87)$ & $7.282(0.001)^{2}$ \\
\hline \multirow[t]{2}{*}{$G Q 3$} & Yes & 322 & $4.35(1.10)$ & \\
\hline & No & 16 & $3.13(1.50)$ & $4.26(<0.001)^{1}$ \\
\hline \multirow[t]{2}{*}{$G Q 4$} & Yes & 147 & $4.18(1.10)$ & \\
\hline & No & 193 & $4.38(1.17)$ & $-1.561(0.120)^{1}$ \\
\hline \multirow[t]{2}{*}{$G Q 5$} & Yes & 86 & $4.37(1.06)$ & \\
\hline & No & 254 & $4.27(1.17)$ & $0.709(0.479)^{1}$ \\
\hline \multirow[t]{2}{*}{$G Q 6$} & Yes & 252 & $4.44(1.03)$ & \\
\hline & No & 87 & $3.85(1.34)$ & $4.277(<0.001)^{1}$ \\
\hline \multirow[t]{2}{*}{$G Q 7$} & Yes & 269 & $4.43(1.08)$ & \\
\hline & No & 70 & $3.73(1.23)$ & $4.691(<0.001)^{1}$ \\
\hline
\end{tabular}

1. T-test 2. F-test

\section{Appendix VI}

Table A5. Absorption mean scores in sub-samples based on Questions GQ 1-7.

\begin{tabular}{|c|c|c|c|c|}
\hline Question & $\begin{array}{l}\text { Participant's } \\
\text { Reply }\end{array}$ & $\mathbf{N}$ & $\begin{array}{l}\text { Mean Absorption } \\
\text { score (SD) }\end{array}$ & $\begin{array}{l}\text { Test statistic (p- } \\
\text { value) }\end{array}$ \\
\hline \multirow[t]{2}{*}{ D1 } & Yes & 85 & $3.66(1.00)$ & \\
\hline & No & 251 & $3.52(1.05)$ & $1.064(0.288)^{1}$ \\
\hline \multirow[t]{4}{*}{ D2 } & Rarely & 77 & $3.26(1.13)$ & \\
\hline & Quite often & 64 & $3.50(0.99)$ & \\
\hline & Often & 85 & $3.66(1.03)$ & \\
\hline & Almost always & 115 & $3.73(0.95)$ & $3.539(0.015)^{2}$ \\
\hline \multirow[t]{2}{*}{ D3 } & Yes & 322 & $3.59(1.02)$ & \\
\hline & No & 16 & $2.97(1.15)$ & $2.348(0.019)^{1}$ \\
\hline \multirow[t]{2}{*}{ D4 } & Yes & 147 & $3.54(0.93)$ & \\
\hline & No & 193 & $3.58(1.10)$ & $-0.380(0.704)^{1}$ \\
\hline \multirow[t]{2}{*}{ D5 } & Yes & 86 & $3.74(1.06)$ & \\
\hline & No & 254 & $3.50(1.02)$ & $1.887(0.060)^{1}$ \\
\hline \multirow[t]{2}{*}{ D6 } & Yes & 252 & $3.67(1.02)$ & \\
\hline & No & 87 & $3.23(0.97)$ & $3.454(0.001)^{1}$ \\
\hline \multirow[t]{2}{*}{ D7 } & Yes & 269 & $3.68(1.05)$ & \\
\hline & No & 70 & $3.09(0.85)$ & $4.960(<0.001)^{1}$ \\
\hline
\end{tabular}

1. T-test 2. F-test

\section{Appendix VII}

Table A6. Classification results based on 17-item UWES scores.

\begin{tabular}{lllll}
\hline $\begin{array}{l}k \text {-means } \\
\text { Clustering }\end{array}$ & Cluster & N & Mean (SD) & Test statistic (p-value) \\
\hline$k=2$ & 1 & 184 & $4.53(0.52)$ & \\
$k=3$ & 2 & 157 & $2.93(0.63)$ & $658.377(<0.001)$ \\
& 1 & 115 & $4.82(0.43)$ & \\
$k=4$ & 2 & 83 & $2.49(0.55)$ & \\
& 3 & 143 & $3.72(0.34)$ & $714.676(<0.001)^{*}$ \\
& 1 & 117 & $3.24(0.30)$ & \\
$k=5$ & 2 & 40 & $2.05(0.47)$ & \\
& 3 & 122 & $4.22(0.25)$ & \\
& 4 & 62 & $5.13(0.35)$ & $956.58(<0.001)^{*}$ \\
& 1 & 49 & $5.23(0.32)$ & \\
& 2 & 68 & $2.80(0.25)$ & \\
& 3 & 90 & $3.55(0.22)$ & \\
& 4 & 113 & $4.35(0.24)$ & \\
& 5 & 21 & $1.69(0.37)$ & $1144.61(<0.001)^{*}$ \\
\hline
\end{tabular}

${ }^{*}$ All pairwise comparisons between clusters are significant at level 5\%

\section{References}

[1] Bakker, A. B., Schaufeli, W. B., Leiter, M. P. \& Taris, W. B. (2008). Work Engagement: an emerging concept in occupational health psychology, Work Stress, 22, 187-200.

[2] Bakker, A. B., Demerouti, E. \& Sanz-Vergel, A. I. (2014). Burnout and Work Engagement: The JD-R Approach, Organizational Psychology and Organizational Behavior, 1, 389-411. 
[3] Bakker, A. B., Shimazu, A., Demerouti, E., Shimada, K. \& Kawakami, N. (2014). Work engagement versus workaholism: a test of the spillover-crossover model, Journal of Managerial Psychology, 29, 63-80.

[4] Breevaart, K., Bakker, A. B., Demerouti, E. \& Derks, D. (2016). Who takes the lead? a multi-source diary study on leadership, work engagement and job performance, Journal of Organizational Behavior, 37, 309-325.

[5] Breevaart, K., Bakker, A. B., Demerouti, E. \& van den Heuvel, M. (2015). Leader-member exchange, work engagement and job performance, Journal of Managerial Psychology, 30, 754-770.

[6] Demerouti, E., Bakker, A. B., De Jonge, J., Janssen, P. P. M. \& Schaufeli, W. B. (2001). Burnout and engagement at work as a function of demands and control, Scandinavian Journal of Work Environment \& Health, 27, 279-286.

[7] Feldt, T., Huhtala, M., Kinnunen, U., Hyvonen, K., Makikangas, A. \& Sonnentag, S. (2013). Longterm patterns of effort-reward imbalance and over-commitment: Investigating occupational well-being and recovery experiences as outcomes, Work \& Stress, 27, 64-87.

[8] Kahn, W. A. (1990). Psychological conditions of personal engagement and disengagement at work, Academy of Management Journal, 33, 692-724.

[9] Mäkikangas, A., Feldt, T., Kinnunen, U. \& Schaufeli, W. B. (2016). The longitudinal development of employee well-being: A systematic literature review, Work \& Stress. 30, 46-70.

[10] Maslach, C., \& Leiter, M. P. (1997). The truth about burnout:
How organizations cause personal stress and what to do about $i t$, San Francisco, CA: Jossey-Bass.

[11] Schaufeli, W. B., Salanova, M., Gonzalez-Roma, V. \& Bakker, A. B. (2002a). The measurement of engagement and burnout: A confirmatory factor analytic approach, Journal of Happiness Studies, 3, 71-92.

[12] Schaufeli, W. B., Martinez, I., Marques Pinto, A., Salanova, M. \& Bakker, A. B. (2002b). Burnout and engagement in university students: A cross national study, Journal of CrossCultural Psychology, 33, 464-481.

[13] Schaufeli, W. B., Taris, T. W. \& Van Rhenen, W. (2008). Workaholism, Burnout and Work Engagement: Three of a Kind or Three Different Kinds of Employee Well-Being, Applied Psychology: An International Review, 57, 173-203.

[14] Schaufeli, W. B. \& Bakker, A. B. (2004). Job demands, job resources and their relationship with burnout and engagement: a multi-sample study, Journal of Organizational Behavior, 25, 293-315.

[15] Schaufeli, W. B. \& Bakker, A. B. (2003). Utrecht work engagement scale: Preliminary manual, Occupational Health Psychology Unit, Utrecht University, Utrecht.

[16] Schaufeli, W. B., Taris, T., Le Blanc, P., Peeters, M., Bakker, A., \& De Jonge, J. (2001). Maakt arbeid gezond? Op zoek naar de bevlogen werknemer, De Psycholoog, 36, 422-428.

[17] Sonnentag, S. (2003). Recovery, work engagement, and proactive behavior (2003), A new Look at the interface between non-work and work, Journal of Applied Psychology, $88,518-528$. 